\title{
Methods of Assessing Odour Emissions from Biogas Plants Processing Municipal Waste
}

\author{
Marta Wiśniewska' \\ 1 Warsaw University of Technology, Faculty of Building Services, Hydro and Environmental Engineering, \\ Ground Surface Protection Team, ul. Nowowiejska 20, 00-653 Warsaw, Poland \\ e-mail: marta.wisniewska.89@wp.pl
}

\begin{abstract}
Waste management is an important element of sustainable urban development. One of the directions of waste management is mechanical-biological treatment (MBT) of waste with biogas installation. In addition to the benefits of purifying waste from separate collection and sorting of raw material waste from the mixed waste stream (subsequently diverted to recovery or recycling), this direction is also characterised by energy benefits (energy production from biogas). Mechanical and biological treatment of municipal waste inevitably entails also negative impacts, such as odour emission. In Poland, there are no legal regulations concerning odour nuisances. Reference could be made, inter alia, to BAT conclusions on waste treatment or standards in other countries. There are many methods of testing for odour emissions, but none of them, taken individually, characterises it sufficiently. The paper presents the results of research carried out in one of the biogas plants in Poland. The results present the sources of the highest odour emission in the examined plant, to which they belong: digestate during oxygen stabilisation $2^{\circ}$ in the open air and pump station of technological sludge.
\end{abstract}

Keywords: biogas plant; municipal waste; odour emission; olfactometry

\section{INTRODUCTION}

The element inherent in waste treatment is the emission of odours. The decomposition of biodegradable waste fractions produces many volatile odoriferous substances, the so-called odorants. (Wiśniewska et al., 2019). The generated and collected municipal waste is most often directed to plants with mechanical-biological waste processing installations. One of the types of plants with MBT installations is biogas plants processing municipal waste. The biogas installations, apart from undoubted benefits resulting from the possibility of waste management, as well as the inclusion of biogas produced in the process of anaerobic decomposition of waste, which is then transformed into electricity and heat, are associated with nuisances resulting from their functioning, i.e: odour and process gas emissions The gases emitted consist of both organic compounds (volatile fatty acids, aldehydes, ketones, alcohols), as well as inorganic (hydrogen sulphide, ammonia) (Cheng et al., 2019; Orzi et al., 2010; Scaglia et al., 2011). In recent years, there has been an increase in fear of new investments being a potential source of the odour, but also a decrease in tolerance to odour nuisance of existing facilities (Capelli et al., 2019; De Feo et al., 2013).

The sources of odour emission in biogas plants processing municipal waste are mainly related to the processes and unit operations carried out on the premises of the plants, as well as the technological regime and type of waste processed. The main sources of odour in this type of objects include:

- facilities and places used for storage and intermediate storage of waste (halls, shelters, reinforced concrete substrates),

- facilities for the pre-treatment of waste (mechanical part of the installation),

- facilities associated with the fermentation process, i. e: the hall for preparing the charge for the fermentation process, the fermentation dewatering station, the hall and the prism yard for the aerobic stabilization of the fermentation, 
- green waste composting sites,

- biogas treatment, storage and cogeneration system,

- equipment for deodorizing process gases, e.g. biofilters (Lapčík and Lapčíkowá, 2011; Vanek et al., 2015; Wiśniewska et al., 2018).

The paper presents the most frequently used methods used in the assessment of odour emission from biogas plants processing municipal waste. Examples of the application of selected methods are presented, and the best available techniques requirements for waste treatment are referred to (Commission Implementing Decision (EU) 2018/1147). This document describes the methods of monitoring the emission to air from waste management plants, including odours.

\section{Methods for assessing the level of emissions from biogas plants processing municipal waste}

In the case of plants for the mechanical-biological treatment of municipal waste, an analysis should be carried out when selecting methods for the assessment of odour emissions:

- the type of waste treatment technology used,

- the type of input to the digesters,

- the type of equipment used to deodorize process gases,

- nature and physical and chemical properties of the gases emitted and the conditions for their dispersion in the air,

- arrangement and working conditions of the ventilation system,

- location of the plant (the type of development in the area around the plant and presence of other potentially odour nuisance plants in the vicinity of the plant under investigation),

- complaints about the smell nuisance of the plant.

In order to identify the problem of odour nuisance of a given object, as well as to apply necessary measures to minimize it, it is usually necessary to integrate several methods using both technical (e. g. measurement studies) and sociological (e. g. analysis of complaints of people living in the vicinity of the examined objects) (Wiśniewska et al., 2018).

\section{Sensory methods}

A sensory assessment consists of evaluating the properties of the samples tested using one or more senses acting as a measuring apparatus. Dynamic olfactometry is the most commonly used method of sensory odour assessment. In dynamic olfactometry, the human nose plays the role of a sensor. The olfactometric method for measuring odour concentrations is to determine the degree of dilution of the gas to be analysed with clean air to obtain a concentration corresponding to the olfactory threshold of sensitiveness. The olfactory threshold is defined as the degree of dilution of a sample at which the odour probability under the measuring conditions is 0.5 ( $50 \%$ of the representative human population smells the odour). The threshold concentration is related to the odour unit (ou), which is defined as the amount of pollutant present in a cubic meter of air at the moment when the threshold is reached. Usually, olfactometers are equipped with one or more stations, allowing samples to be presented to two, four, six or eight people at the same time. Differences in the design are also due to the measuring range and the possibility of automatic calibration (Barczak and Kulig, 2017; Grzelka et al., 2018; PN-EN 13725:2007; Szyłak-Szydłowski, 2018).

Procedures related to the determination of odour concentration by dynamic olfactometry and gas sampling are included in the Polish standard PN-EN 13725 Air quality. Detection of odour concentration by dynamic olfactometry (PN-EN 13725:2007).

Dynamic olfactometry according to (Biasioli et al., 2004) is the most direct and reliable tool for assessing the odour impact of both individual odorants and their mixtures, which are emitted, among others, from mechanical-biological waste treatment plants, which include biogas plants processing municipal waste.

Dynamic olfactometry can be divided into the laboratory (indirect) and field (direct). Gas samples in indirect olfactometry are collected in bags, usually Tedlar Bags ${ }^{\circledR}$ (Szyłak-Szydłowski, 2015) and sent to the laboratory equipped with a stationary dynamic olfactometer. Using this olfactometer, a gas sample is presented to a research team (Bliss et al., 1996; Schulz and van Harreveld, 1996; Sówka, 2011. The undoubted disadvantage of this method is the high risk of changes in the chemical composition of the mixture of the transported gas sample, which affects the result 
of odour concentration during the determination in the laboratory. Usually, this result is lower than in the case of direct olfactometry (Bokowa, 2012; Szyłak-Szydłowski, 2019).

Direct (field) olfactometry, in contrast to indirect (laboratory) olfactometry, consists in the analysis of air directly at the source. The most important advantage of this method is the minimization of chemical reactions in the tested gas sample during transport between the source of odours and the research laboratory. The disadvantage of this method is the high costs associated with the departure of probants (Szyłak-Szydłowski, 2019).

In addition to dynamic olfactometry, odour measurement techniques also include static olfactometry, which consists of Triangle Odor Bag Method. Probants, i. e. assessors, who are presented with three samples, are asked to indicate in which sample the smell is felt. This method, as in the case of dynamic olfactometry, allows the determination of the degree of dilution at which a smell can be detected, but it is done by mixing a specific volume of the sample in a specific volume of clean air (Grzelka et al., 2018; Kośmider et al., 2002; Szyłak-Szydłowski, 2019).

\section{Analytical methods}

Sensory methods are ideal for testing odour as a mixture, as opposed to the analysis of specific odorant chemicals. In the latter case, the anthropometric method is used. Using the sensory method, the chemical composition of the tested gas sample remains unrecognized (Laor et al., 2014). An example of an analytical method is gas chromatography coupled with mass spectrometry. According to (Rincon et al., 2019), this method is less expensive than sensory methods and is not dependent on the reaction to the human sense of smell.

However, the chemical composition does not give full information about the smell. Compounds in a gas mixture can contribute to other, more or less complex processes. The range of odour stimulus depends on the thresholds of odour detection, as well as chemical and physiological interactions (Kim and Park, 2008; Rincon et al., 2019). The use of only one method will not be sufficient. An alternative solution may be to use an analysis of the fragrance activity values, enabling the concentration of odorants and their odorant potential to be linked (Rincon et al., 2019).

\section{Sensor methods}

An example of using the sensor method is enose. This method allows for continuous odour monitoring and reduces the need for multiple samples. The disadvantages of this method are mainly related to the necessity to undergo appropriate training by persons operating the equipment, as well as to the coding of often complicated mathematical and statistical algorithms responsible for the correct interpretation of the results (Gębicki et al., 2017).

The operation of the electronic nose is based on the use of a sensor matrix that converts the supplied chemical information into a useful analysis signal. The task of e-nose is to record the characteristics of a mixture of volatile substances depending on the concentration of specific components of a given odour. Sensor methods, on the one hand, mitigate the dysfunctions of the human nose, but on the other hand, they limit the measurement to the pollutants and concentration ranges to "learned» through the electronic nose (Grzelka et al., 2018). Besides, electronic noses are characterized by a high sensitivity of the device (Szyłak-Szydłowski, 2019).

\section{Indicators of the emission of odours from the mechanical and biological installations of waste treatment}

The total value of emissions of the odorants, representing the sum of emissions from each emission source, can be calculated using the formula (Szyłak-Szydłowski, 2018; ÚBeda et al., 2010):

$$
E=\sum_{i=1}^{n} E_{i}=\sum_{i=1}^{n}\left(E_{i} \cdot A_{i} \cdot f_{c i}\right),
$$

where: $E$ - total odorant emissions [ou/s], $E_{I}-$ odour stream of odorants and $[\mathrm{ou} / \mathrm{s}]$, $E_{e i}$ - odour stream of odorants and $\left[\mathrm{ou} / \mathrm{m}^{2} \cdot \mathrm{S}\right]$,

$A_{I}$ - source area i $\left[\mathrm{m}^{2}\right]$,

$F_{c i}$ - odour control coefficient from source and [-] (depending on the type of odour minimisation technology applied: biofilters, encapsulation, etc.). Its values range from 0.1 to 0.6 ) in case of non-application of technology to minimize odour nuisance, the coefficient equals 1 . 
Table 1. Values of odour emission rates for the projected treatment waste facility (Boholt et al., 2002; Sironi et al., 2005; Úbeda et al., 2010)

\begin{tabular}{|c|c|}
\hline Type of waste & $\begin{array}{c}\text { Odour emission rate } \\
{\left[\mathrm{ou} / \mathrm{m}^{2} \cdot \mathrm{s}\right]}\end{array}$ \\
\hline Municipal solid waste & 59,0 \\
\hline Active composting areas & 150,0 \\
\hline Maturation areas of compost & 42,0 \\
\hline Final compost & 5,0 \\
\hline
\end{tabular}

In Table 1, the emission values of the odorants for various types of economic activities fall off. Sironi el al. (2007) proposed another method of calculating the emission level of fragrances:

$$
O E R=A \cdot O E F \cdot\left(1-\frac{O R E}{100}\right)
$$

where: $O E R$ - the level of odour emission [ou/s], $A$-index of the activity (parameter, which is a characteristic value, associated with the emission of odours, e.g.: the capacity of the installation, total production of the waste mass, the surface of the installation, $O E F$ - emissions of odours, $O R E$ - total odours reduction [\%].

$$
O R E=\frac{c_{O d_{I N}}-c_{o d_{O U T}}}{c_{O d_{I N}}} \cdot 100
$$

where: $c_{\text {odIN }}$ - odour concentration measured at the entrance to the deodorization plant, $c_{\text {odUT }}$ - odour concentration measured at the exit of the process air deodorizing plant.

Unification of waste management facilities, in terms of their fragrance impact, for the needs of modelling is practically impossible. Many different and variable factors, such as the morphology of waste delivered to the plant, meteorological conditions, technological regime, including the way of conducting processes, have an impact on the emission of malicious substances from mechanical-biological processing installations, which include biogas plants processing municipal waste. Therefore, model calculations should not replace direct research (Drew et al., 2007; Sanchez-Mondero et al., 2003). Besides, biogas plants processing municipal waste are characterised by a variety of types of odour sources. The BAT conclusions (Commission Implementing Decision (EU) 2018/1147) concerning waste treatment characterise these sources as:
- sources of organized emission - these are sources of emission of polluting substances to the environment through all kinds of ducts, pipes, chimneys or open biofilters,

- diffuse emission sources - these are sources of non-scanned emissions, including volatile organic compounds and odour), which may originate from areal sources (e.g. tanks) or point sources (e.g. pipe flanges). The sources of diffuse emission also include composting prisms in the open air,

- fugitive emission sources - these are sources of diffuse emission from point sources.

However, the above division does not exhaust the characteristics of all sources of emission of catch substances in biogas plants generating municipal waste. In the case of composting or aerobic stabilisation of digestate, waste is often not collected in prisms, is irregular in shape and there is no visible boundary between successive batches of waste.

\section{Methods of process gas sampling in odour emission tests in biogas plants processing municipal waste}

The most important issue when sampling gas for olfactometric determinations is its odour representativeness. Improper sampling for analysis may affect the occurrence and magnitude of errors. Errors may also be due to the characteristics of the source of the odours, as well as the characteristics of the gases and the parameters of the equipment used for the determination. In the case of olfactometric determinations, the serums of a gas mixture in trace amounts can have a significant influence on the determination result. For this reason, the sample must not undergo even the smallest changes in composition, because odorants are compounds with active functional groups that are susceptible to change (SzyłakSzydłowski, 2018).

In the case of surface sources, various types of shielding are most frequently used to take a gas sample, the purpose of which is, on the one hand, to minimise the external factors which may affect the determination result and, on the other hand, to determine the flow necessary to calculate the emissions from the source. It is important to know the amount of air extracted from under the dome. We distinguish between Lindval shields, static flow chambers and dynamic flow chambers. Samples, for each 


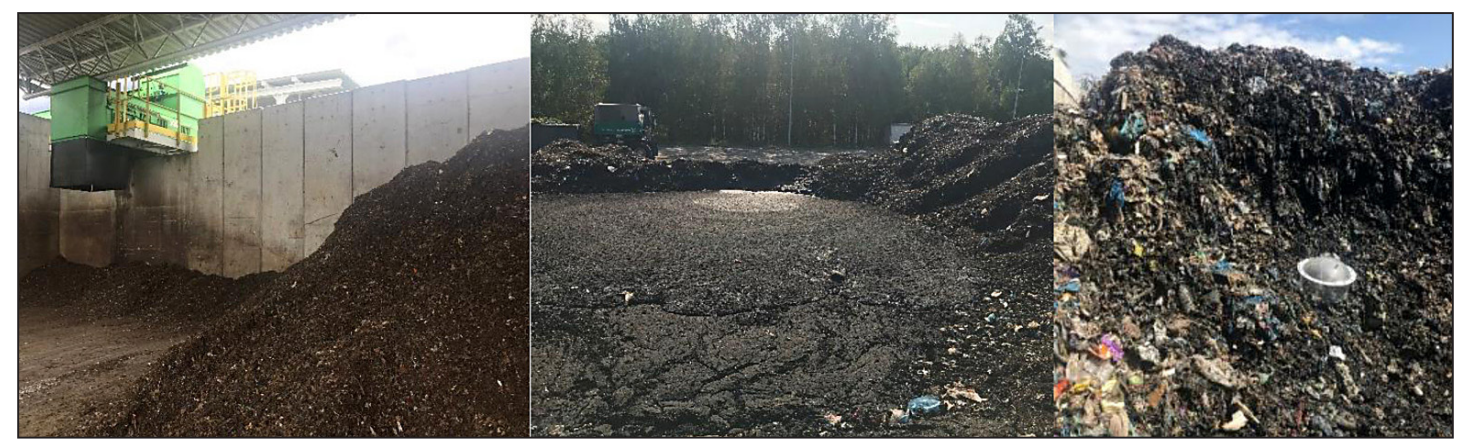

Fig. 1. Wastes subjected to composting/aerobic stabilisation - various solutions (own photography)

chamber, are taken at the outlet of the casing. Each time after the shield has been placed on the surface of the source, wait until the pressure under the shield is balanced before taking the gas sample (Szyłak-Szydłowski, 2018). This time depends on the shape and dimensions of the shield (Naddeo et al., 2012).

\section{The odour standards and legal regulations in Poland concerning waste processing}

In Poland, despite complaints from residents living in the vicinity of municipal waste mechanical-biological processing plants, which also include biogas plants processing municipal waste, there are no statutory solutions dedicated to odour emission and odour nuisance problems in the Polish legal system. In Poland, there are regulations that only indirectly address the problem of odour emissions. The most important is the Act of 27 April 2001. Environmental Protection Law (i.e. Journal of Laws 2019, item 1396) and the Regulation on reference values for certain substances in the air. (Journal of Laws of 2010, No. 16, item 87).
Averaged reference values for selected chemical compounds, characteristic for such projects as biogas plants processing municipal waste (Wiśniewska et al., 2019) are presented in Figure 2.

A European Union Commission Decision establishing BAT conclusions on waste treatment (Commission Implementing Decision (EU) 2018/1147) was issued on August 2018. In this document, e. g. emulsions to air from mechanicalbiological waste treatment installations have been designated. Table 2 shows the emission levels for certain substances from biological treatment of waste. It is worth noting that BAT conclusions, using the notion of air emission, operate with odour concentrations and odorants (ammonia and volatile organic compounds).

\section{RESULTS AND DISCUSSION}

Table 3 presents the results of measurements carried out in one of the biogas plants in Poland. The study included measurements of odour concentration by dynamic field olfactometry and

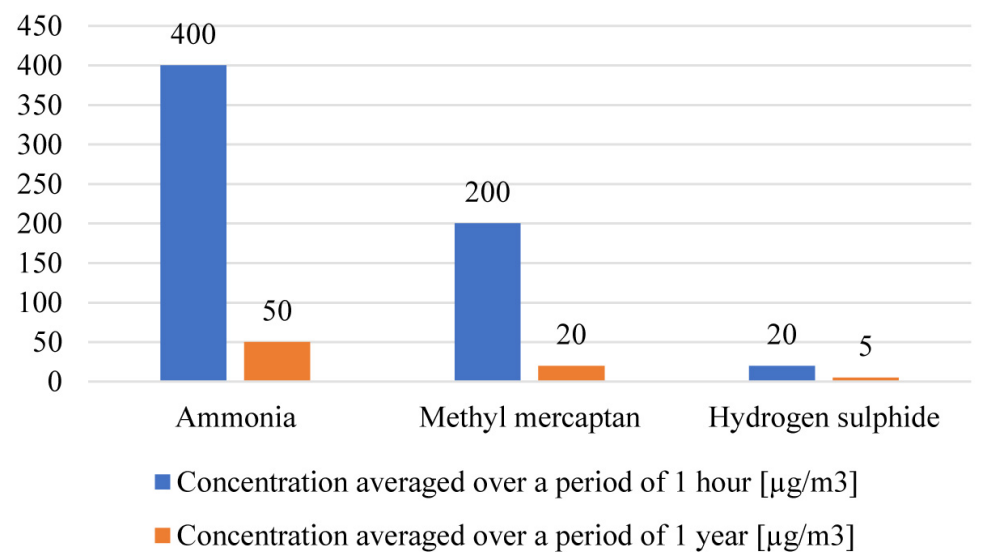

Fig. 2. Example reference values for odorants included in the Ordinance of the Minister of the Environment of 26 January 2010 on reference values for certain substances in the air (Dz. U. of 2010, No. 16, item. 87) 
Table 2. Emission levels associated with best available techniques for organised air emissions of certain substances from biological treatment of waste (Commission Implementing Decision (EU) 2018/1147)

\begin{tabular}{|c|c|c|}
\hline Parameter & Unit of measure & $\begin{array}{c}\text { Average over the } \\
\text { sampling period }\end{array}$ \\
\hline Ammonia & $\mathrm{mg} / \mathrm{m}^{3}$ & $0.3-20$ \\
\hline $\begin{array}{c}\text { Odour } \\
\text { concentration }\end{array}$ & $\mathrm{ou} / \mathrm{m}^{3}$ & $200-1000$ \\
\hline Total VOC & $\mathrm{mg} / \mathrm{m}^{3}$ & $5-40$ \\
\hline
\end{tabular}

ammonia, hydrogen sulfide, methyl mercaptan and volatile organic compounds using a portable gas detector with a pumping system. The methodology of research has been described in the works (Wiśniewska et al., 2018; Wiśniewska et al., 2019).

Presentative results of research that the sources of the highest odour concentrations are: digestate during oxygen stabilisation $2^{\circ}$ in the open air and pump station of technological sludge $\left(246 \mathrm{ou} / \mathrm{m}^{3}\right)$. Ammonia concentration at the level of $4 \mathrm{ppm}$ may indicate anaerobic transformations in uncontrolled conditions. In turn, very high concentrations of ammonia and volatile ammonia compounds were obtained based on waste submitted to aerobic stabilization in the open air. Such a high emission of catch compounds may be related to the insufficient time of fermentation process (technological regime). The pumping station of technological wastewater is also a source of fragrances. At this measurement point, unlike the others presented in Table 3, hydrogen sulphide and methyl mercaptan are also emitted.

\section{CONCLUSIONS}

Biogas plants processing municipal waste, which are an important element of municipal infrastructure, also provide an important source of energy. Apart from many benefits, the analysed investments are characterized by a negative impact - the emission of odours. There are many methods in place to assess emissions of nonferrous matter. The use of only one method may not be enough. Analysing only the concentration of chemical compounds (odorants), we do not

Table 3. The odour emission levels from a biogas plant processing municipal waste in Poland for selected odour sources

\begin{tabular}{|c|c|c|c|c|}
\hline No. & Kind of source & Parameter & Unit & Concentration \\
\hline \multirow{5}{*}{1} & \multirow{5}{*}{ Mixed waste } & Odour concentration & $\mathrm{ou} / \mathrm{m}^{3}$ & 22 \\
\hline & & Ammonia & ppm & 1 \\
\hline & & Hydrogen sulphide & ppm & $<0.1$ \\
\hline & & Methyl mercaptan & ppm & $<0.1$ \\
\hline & & VOC & $\mathrm{ppb}$ & 6970 \\
\hline \multirow{5}{*}{2} & \multirow{5}{*}{ Selective waste } & Odour concentration & $\mathrm{ou} / \mathrm{m}^{3}$ & 6 \\
\hline & & Ammonia & ppm & 1 \\
\hline & & Hydrogen sulphide & ppm & $<0.1$ \\
\hline & & Methyl mercaptan & ppm & $<0.1$ \\
\hline & & VOC & $\mathrm{ppb}$ & 4240 \\
\hline \multirow{5}{*}{3} & \multirow{5}{*}{$\begin{array}{l}\text { The substrate prepared for } \\
\text { fermentation }\end{array}$} & Odour concentration & $\mathrm{ou} / \mathrm{m}^{3}$ & 22 \\
\hline & & Ammonia & $\mathrm{ppm}$ & 4 \\
\hline & & Hydrogen sulphide & ppm & $<0.1$ \\
\hline & & Methyl mercaptan & ppm & $<0.1$ \\
\hline & & VOC & $\mathrm{ppb}$ & 25410 \\
\hline \multirow{5}{*}{4} & \multirow{5}{*}{$\begin{array}{l}\text { Digestate during oxygen } \\
\text { stabilisation } 2^{\circ} \text { in the open air }\end{array}$} & Odour concentration & $\mathrm{ou} / \mathrm{m}^{3}$ & 246 \\
\hline & & Ammonia & ppm & $<100$ \\
\hline & & Hydrogen sulphide & ppm & $<0.1$ \\
\hline & & Methyl mercaptan & ppm & $<0.1$ \\
\hline & & VOC & $\mathrm{ppb}$ & $<18000$ \\
\hline \multirow{5}{*}{5} & \multirow{5}{*}{$\begin{array}{l}\text { Pump station of technological } \\
\text { sludge }\end{array}$} & Odour concentration & $\mathrm{ou} / \mathrm{m}^{3}$ & 246 \\
\hline & & Ammonia & ppm & 17 \\
\hline & & Hydrogen sulphide & ppm & 0.4 \\
\hline & & Methyl mercaptan & ppm & 0.3 \\
\hline & & VOC & $\mathrm{ppb}$ & 2990 \\
\hline
\end{tabular}


get full information about the smell, because we only examine selected compounds. Very often, compounds in small quantities can be decisive for odour.

High variability of such parameters as waste morphology, technological regime, method of conducting technological processes, but also meteorological conditions, makes it very difficult to model odour emission from biogas plants processing municipal waste, as well as other mechanical-biological waste processing plants (Szyłak-Szydłowski, 2018).

The conducted analyses and own research show that sensory methods are of great importance for the assessment of odour emissions from waste management plants. Due to the high dynamics of changes related to the emission of odours in biogas plants, the emission studies conducted over a longer period of time and with a higher frequency may be of scientific significance, in order to find dependencies between the emission and morphology of waste, the technological regime, technological processes and meteorological conditions prevailing both during the research and during the collection of waste before it reaches the plant.

\section{REFERENCES}

1. Barczak R., Kulig A. 2017. Comparison of different measurement methods of odour and odorants used in the odour impact assessment of wastewater treatment plants in Poland. Water, Science and Technology, 75 (4), 944-951. https://doi.org/10.2166/ wst.2016.560

2. Biasioli F., Gasperi F., Odorizzi G., Aprea E., Mott D., Marini F., Autiero G., Rotondo G., D. Märk T. 2004. PTR-MS monitoring of odour emissions from composting plants. International Journal of Mass Spectrometry 239, 103-109.https://doi. org/10.1016/j.ijms.2004.07.024

3. Bliss, P. J., Schulz, T. J., Senger, T., Kaye, R. B. 1996. Odour measurement - factors affecting olfactometry panel performance. Water Science and Technology, 34, 549-556.

4. Boholt K., Oxbol A. 2002. Odour measurement on composting plants with biodegradable municipal waste-experience with different sampling techniques. Teknik energy and environment, Copenhagen, Denmark, 2002.

5. Bokowa A. 2012. Ambient odour assessment similarities and differences between different techniques. Chemical Engineering Transactions, 30, 313-318. https://doi.org.10.3303/CET1230053
6. Capelli L., Sironi S., Del Rosso R., Céntola P., Rossi A., Austeri C. 2011. Odour impact assessment in urban areas: case study of the city of Terni. Procedia Environmental Sciences, 4, 151-157. https ://doi. org/10.1016/j.proenv.2011.03.018

7. Cheng Z., Sun Z., Zhu S., Lou Z., Zhu N., Feng L. 2019. The identification and health risk assessment of odor emissions from waste landfilling and composting. Science of the Total Environment, 649. https://doi.org/10.1016/j.scitotenv.2018.08.230

8. Decisions Commission Implementing Decision (EU) 2018/1147 of 10 August 2018 establishing best available techniques (BAT) conclusions for waste treatment, under Directive 2010/75/EU of the European Parliament and of the Council.

9. De Feo G., De Gisi S., Williams I.D. 2013. Public perception of odour and environmental pollution attributed to MSW treatment and disposal facilities: a case study. Waste Management, 33(4), 974-987. https ://doi.org/10.1016/j.wasma n.2012.12.016

10. Drew G. H., Smith R., Gerard V., Burge C., Lowe M., Kinnersley R. P., Sneath R. W., Longhurst P. J. 2007. Appropriateness of selecting different averaging times for modelling chronic and acute exposure to environmental odours. Atmospheric Environment, 41 (13), 2870-2880. https://doi.org/10.1016/j. atmosenv.2006.09.022

11. Gębicki J., Dymerski T., Namieśnik J. 2017. Investigation of Air Quality beside a Municipal Landfill: The Fate of Malodour Compounds as a Model VOC. Environments, 4, 7. https://doi.org/10.3390/ environments4010007

12. Grzelka A., Sówka I., Miller U. 2018. Methods for assessing the odor emissions from livestock farming facilities. Journal of Ecological Engineering (in Polish), 19 (2), 56-64.

13. Kim K.H., Park, S.Y. 2008. A comparative analysis of malodor samples between direct (olfactometry) and indirect (instrumental) methods. Atmospheric Environment, 42, 5061-5070. https://doi. org/10.1016/j.atmosenv.2008.02.017

14. Kośmider J., Mazur-Chrzanowska B., Wyszyński B. 2002. Odours (in Polish), Wydawnictwo Naukowe PWN.

15. Lapčík V., Lapčíkowá M. 2011. Environmental Impact Assessment of Biogas Stations in the Czech Republic. Polish Journal of Chemical Technology. 13, 3, 18-22. https:/doi.org/10.2478/v10026-011-0031-8

16. Laor, Y., Parker, D., Pagé, T. 2014. Measurement, prediction, and monitoring of odors in the environment: A critical review. Reviews in Chemical Engineering. 30, 139-166. https://doi.org/10.1515/ revce-2013-0026

17. Naddeo V., Belgiorno V., Zarra T. 2012. Odour Impact Assessment Handbook, John Wiley \& Sons, Ltd. 
18. Orzi V., Cadena E., D’Imporzano G., Artola A., Davoli E., Crivelli M., Adani F. 2010. Potential odour emission measurement in organic fraction of municipal solid waste during anaerobic digestion: Relationship with process and biological stability parameters. Bioresource Technology 101, 7330-7337. https://doi.org/10.1016/j.biortech.2010.04.098

19. PN-EN 13725:2007. 2007. Air quality. Determination of the odour concentration by dynamic olfactometry (in Polish).

20. Rincon C. A., De Guardia A., Couvert A., Wolbert D., Le Roux S., Soutrel I., Nunes G. 2019. Odor concentration (OC) prediction based on odor activity values (OAVs) during composting of solid waste and digestates. Atmospheric Environment, 201. https://doi.org/10.1016/j.atmosenv.2018.12.030

21. Sanchez-Mondero M. A., Stentiford E., Mondini C. 2003. Biofiltration at composting facilities: effectiveness for bioaerosol control. Environmental Science and Technology, 37 (18), 4299-4303.

22. Scaglia B, Orzi V., Artola A., Font X., Davoli E., Sanchez A., Adani F. 2011. Bioresource Technology Odours and volatile organic compounds emitted from municipal solid waste at different stage of decomposition and relationship with biological stability. Bioresource Technology, 102 (7), 4638-4645. https://doi.org/10.1016/j.biortech.2011.01.016

23. Schulz, T. J. \& van Harreveld, A. P. 1996. International moves towards standardisation of odour measurement using olfactometry. Water Science and Technology, 34, 541-547.

24. Sironi S., Capelli L., Céntola P., Del Rosso R., Il Grande M. 2005. Odour emission factors for assessment and prediction of Italian MSW landfills odour impact. Atmospheric Environment, 39 (29), 5387-5394.

25. Sironi S., Capelli L., Céntola P., Del Rosso R., Il Grande M. 2007. Odour emission factors for assessment and prediction of Italian rendering plants odour impact. Chemical Engineering Journal, 131, 225-231.
26. Sówka I. 2011. Olfactory impact assessment of the selected agri-food processing plant by dynamic olfactometry and computational methods. Proc. of ECOpole, 5 (1), 317-323.

27. Szyłak-Szydłowski M. 2015. Odour samples degradation during detention in Tedlar® bags. Water, Air \& Soil Pollution 226:227. https://doi.org/10.1007/ s11270-015-2495-2

28. Szyłak-Szydłowski M. 2018. Olfactometric method for assessing the degree of biostabilization of waste in mechanical-biological processing installations (in Polish). Oficyna Wydawnicza Politechniki Warszawskiej. Warszawa.

29. Szyłak-Szydłowski M. 2019. Determination of the odour concentration using field olfactometry method (in Polish), Gaz, Woda i Technika Sanitarna, 4, 131-134. https://doi.org/10.15199/17.2019.4.3

30. Úbeda Y., Ferrer M., Sanchis E., Calvet S., Nicolas J., Lopez P. A. 2010, Evaluation of odour impact from a landfill area and a waste treatment facility through the application of two approaches of a Gaussian dispersion model. Proc. of 5th International Congress on Environmental Modelling and Software - Ottawa, Ontario, Canada - July 2010.

31. Vanek M., Mitterpach J., Zacharova A. 2015. Odour control in biogas plant - case study. Poc. 15th International Multidisciplinary Scientific GeoConferences SGEM2015, 353-360.

32. Wiśniewska M., Kulig A., Lelicińska-Serafin K. 2018. Identification and preliminary characteristics of odour sources in biogas plants processing municipal waste. Proc. InfoGlob 2018, SHS Web of Conferences 57, 02016 https://doi.org/10.1051/ shsconf/20185702016

33. Wiśniewska M., Kulig A., Lelicińska-Serafin K. 2019. Comparative analysis of preliminary identification and characteristic of odour sources in biogas plants processing municipal waste in Poland. SN Applied Sciences, 1:550. https://doi.org/10.1007/ s42452-019-0534-0 